\title{
MONETARY VALUATION BY APPLYING PENALTY RATE ON BIRD POPULATION AT KENYIR LAKE RAINFOREST, MALAYSIA
}

\author{
MUHAMAD NASUHA JAAFAR ${ }^{1}$, MARLINDA ABDUL MALEK ${ }^{2}$ AND JAMILAH MOHD \\ SALIM $^{3 *}$
}

${ }^{1}$ Department of Civil Engineering, ${ }^{2}$ Institute of Sustainable Energy, Universiti Tenaga Nasional, Malaysia. ${ }^{3}$ Institute of Tropical Biodiversity and Sustainable Development, Universiti Malaysia Terengganu, Malaysia.

*Corresponding author: munaja517@gmail.com

Submitted final draft: 31 May $2020 \quad$ Accepted: 9 June 2020

http://doi.org/10.46754/jssm.2021.07.012

\begin{abstract}
A variety of methods have been used by researchers to monetise the value of birds in the forest ecosystem. In this study, a valuation method based on fines and penalty rate imposed on poachers or individuals who commit offenses that contribute to the destruction of wildlife of birds listed under Malaysia Wildlife Conservation Act 2010 has been used to estimate monetary value of bird population study conducted at Kenyir rainforest. For the purpose of this study, secondary data on bird population recorded at Kenyir rainforest was used. The result suggests that monetary value of birds in the study area was estimated to be in the MYR 2.07 million to MYR 6.9 million range. The exercise of converting the direct value of birds in monetary terms is important to assist in the determination of the value of wildlife in the eyes of the Malaysian law and its people to make them more appreciative of the value of wildlife in the forest ecosystem.
\end{abstract}

Keywords: Monetary valuation, birds value, ecosystem service, sustainability.

\section{Introduction}

The global forest ecosystem harbours unique flora and fauna, including several species of birds. According to BirdsLife International, Malaysia is home to 718 different species of birds. 64 of them are globally threatened birds and 8 are country endemic. The forest ecosystem provides many things that benefit human beings these benefits are known as ecosystem services. MEA 2005, defines ecosystem services as benefits obtained directly or indirectly from ecosystems - the goods and services of nature and are closely linked to human wellbeing. Ecosystem services are categorised into four classes. The first is provisioning services; i.e. products obtained from the ecosystem. The second is regulating services; benefits obtained from ecosystem processes. The third is cultural services; non-material benefits obtained from the ecosystem and the fourth is supporting services; services necessary to produce all other ecosystem services (MEA, 2005).

Birds contribute to all four types of ecosystem services. As members of ecosystems, birds play many roles and contribute regulating and supporting services via their foraging ecology. These services include scavenging carcasses, nutrient cycling, seed dispersal, pollination, and pest control (Whelan et al., 2008). Birds are also observed, fed, and used as artistic and spiritual inspiration by millions of people around the globe. Birds also play an important role as an indicator to the sustainability of an ecosystem (O'connell et al., 2001). From the notion of the canary in the coal mine, to the influential book Silent Spring by Carson (1962), birds have long been appreciated as an early indicator of changes in environmental quality (Kolstoe and Cameron, 2017).

Yet the economic relevance of birds is not widely appreciated and the economic relevance to human society of birds' ecological roles is even less understood (Whelan et al., 2015). Birds are examples of a forest service that lacks value in the market and generally their value to the society is unmeasured. Furthermore, because the economic benefits of birds are measured in qualitative form, like social benefits, the benefits of the birds are usually underestimated (Amiry et al., 2009). 
Perhaps, expressing the value of birds in monetary unit is a way to convey the importance and value of birds in the forest ecosystem to the eyes of people. Quantifying the value of birds is crucial to understand their importance for the ecosystems and for the people that benefit from them. Biodiversity and its associated ecosystem services can no longer be treated as inexhaustible and free goods and their true value to society and the costs associated with their loss needs to be properly accounted for (Costanza et al., 2014). The economic value associated with the birds can be examined in the form of use and non-use values. Use value includes nonconsumptive use value such as sightseeing, birds watching, photographing, and education. The effects of birds on ecology may include being enemies of many insects, pollinators of flowers, and disseminators of seeds can be referred to as an indirect use value which are unmeasured by conventional market mechanisms (Amiry et al., 2009).

Although the economic valuation of birds is categorised as intangible value, especially with the value of the currency but there are several techniques for measuring the birds value. To date, contingent valuation method has been the most widely used technique for non-use value. This is probably due to its ability to estimate all types of values in particular non-use value of ecosystem goods and services. There have been hundreds of contingent valuation applications worldwide.

Open-ended questions, bidding games and dichotomous choice questions are the main elicitation formats. Dichotomous choice, among other formats for contingent valuation study, is the most recommended because of its ability to match the way consumers make choices in the marketplace. Also, the format improves the reliability of responses (Amiry et al., 2009). Furthermore, non-use value involves ascertaining how much an individual is willing to pay (WTP) to ensure that the existence and heritage attributes of the bird species are preserved while the use value is estimated through eco-tourism services offered by bird parks or bird sanctuaries (JPSM, 2017).

Alternatively, monetary valuation of birds could be conducted using a proxy value based on fines and penalty rate for hunting and capturing bird species listed under Malaysia Wildlife Conservation Act 2010 (JPSM, 2017). Wildlife Conservation Act 2010 is aimed to provide a protection and conservation of wildlife and for matters connected therewith. This Act provides for the regulation, protection, conservation and management of wildlife in Malaysia. The Act applies to the Peninsular Malaysia and the Federal Territory of Labuan. This Act does not apply to any wildlife falling within List II of the Ninth Schedule of the Federal Constitution and the Fisheries Act 1985 [Act 317]. This Act contains nine parts and seven schedules. The offences and penalties are described in part seven, which include offenses relating to licences, offences relating to permits, offences relating to special permits and miscellaneous (Wildlife Conservation Act, 2010).

In this study, similar method was applied to put monetary value on the bird population study conducted at Kenyir rainforest. There is a lack of published data on bird study conducted at Kenyir rainforest, was limited for only three surveys of bird assemblage available by Sulaiman et al., (2015), David et al., (2017) and Nelson et al., (2018). Two of them were surveys conducted at Tanjung Mentong area.

The first preliminary survey of the birds at Tanjong Mentong was conducted by Sulaiman et al., (2015) with a total of 21 individual birds comprising 12 species belonging to 10 families were recorded during the sampling period.

The second survey was conducted at Tanjung Mentong by David et al., (2017) with result of total of 50 individuals comprising 25 species belonging to 20 families were recorded during this survey. A third study on bird counts was conducted by Nelson et al., (2018) at an identified trail at Kenyir rainforest with 94 individuals belonging to 25 species of selected iconic avian species. 
Table 1: Previous study on bird survey at Kenyir rainforest

\begin{tabular}{|c|c|c|c|}
\hline & Study 1 & Study 2 & Study 3 \\
\hline Subject & $\begin{array}{l}\text { Preliminary survey of } \\
\text { birds assemblage at } \\
\text { Tanjong Mentong }\end{array}$ & $\begin{array}{l}\text { Checklist of birds at } \\
\text { Tanjong Mentong }\end{array}$ & $\begin{array}{l}\text { Iconic Avian data from } \\
\text { Kenyir Rainforest Trail }\end{array}$ \\
\hline Authors & Sulaiman et al. (2015) & David et al. (2017) & Nelson et al. (2018) \\
\hline Total no. of individuals & 21 & 50 & 94 \\
\hline Total no. of species & 12 & 25 & 25 \\
\hline Methods used & Mist-netting & $\begin{array}{l}\text { Mist-netting and point } \\
\text { count }\end{array}$ & $\begin{array}{l}\text { Transect construction and } \\
\text { visualize using binocular } \\
\text { and DSLR camera }\end{array}$ \\
\hline Duration of survey & 4 net-days & 6 sampling days & 5 months count data \\
\hline
\end{tabular}

\section{Materials and Methods}

\section{Study Site}

The study on converting the value of birds in monetary terms was applied to the bird population at the Kenyir rainforest. Kenyir is a luxurious forest located Hulu Terengganu district, which lies at a longitude of 102 degree 40 minutes and a latitude of 4 degrees and 40 minutes. Standing about 138 meters above sea level, Kenyir lake is surrounding by tropical rainforest with rich and valuable flora and fauna. In the north is Hulu Telemong Forest Reserve and in the south is Hulu Terengganu Forest Reserve. This leads to the National Park. Kenyir lake is the largest man-made freshwater lake at Malaysia. Covering more than 340 islands spread out in water catchments area of 38,000 hectares. The lake is known as a unique tourist destination for its beautiful tropical forest and widely known for its valuable wood species, plants, animals, birds and insects. Rich with numerous types of flora and fauna its boundary leads to endless discoveries and adventures. Its beautiful aesthetic views of flora and fauna are attracting tourists to enjoy being in natural habitat. Kenyir Lake is one of the most popular destinations for recreation and birding activities.

\section{Flowchart of Estimation on the Monetary Value of Bird}

Estimation on the monetary value of birds was conducted using fines and penalties rate coded by Wildlife Conservation Act 2010 (Act 716) on hunters or individuals who commit offenses that contribute to the destruction of wildlife of birds. According to Act 716, protected wildlife means any wildlife specified in the First Schedule and totally protected wildlife means any wildlife specified in the Second Schedule. Each individual of birds from the latest survey by Nelson et al. (2018) at Kenyir rainforest then classified into protected or totally protected species accordingly. The flowchart below illustrates the application in this study. 


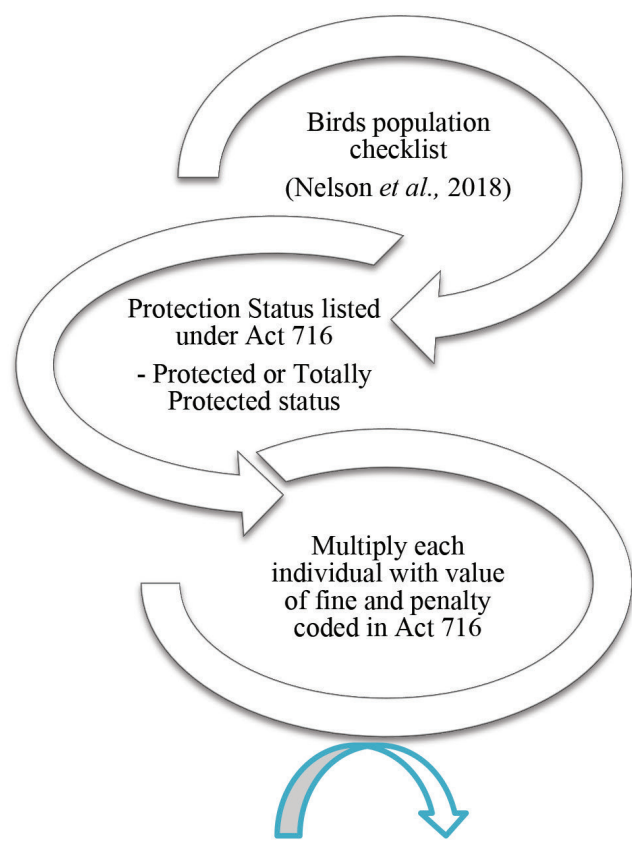

Value of protected + totally protected species $=$ Monetary value of birds

Figure 1: Flowchart of estimation on the monetary value of birds

\section{Relation between Offences and Penalties Value with Protected and Totally Protected Species in Wildlife Conservation Act 2010}

In Wildlife Conservation Act 2010 (Act 716), Part VII elaborates offences and penalties and outlines the fine rate for any person who commits an offence in hunting protected (chapter 1) and totally protected bird species (chapter 3). Chapter 1 stated that any person who without a license commits an offence in hunting protected birds and on conviction shall be liable to a fine not exceeding fifty thousand ringgit (MYR 50,000.00). Chapter 3 stated that any person who without a special permit commits an offence in hunting totally protected birds and on conviction shall be liable to a fine not exceeding a hundred thousand ringgit (MYR 200,000.00). The information on fine and penalty rates for protected and totally protected wildlife of birds is summarised below:

Table 2: The fine and penalty rate for protected and totally protected species

\begin{tabular}{ll}
\hline \multicolumn{1}{c}{ Category } & \multicolumn{1}{c}{ Fine and Penalty rate } \\
\hline $\begin{array}{l}\text { Protected (Chapter 1) } \\
\text { Protected species }\end{array}$ & Not more than MYR 50,000 \\
$\begin{array}{l}\text { Specific species: } \\
\begin{array}{l}\text { Common Shama (Copsychus malabaricus) } \\
\text { Oriental White Eye (Zosterops palpebrosa) }\end{array} \\
\text { Hill Myna (Gracula religiosa) }\end{array}$ & $\begin{array}{l}\text { heads, shall on conviction be punished with a } \\
\text { fine of not less than twenty thousand ringgit and } \\
\text { not more than fifty thousand ringgit) }\end{array}$ \\
\hline $\begin{array}{l}\text { Totally Protected (Chapter 3) } \\
\text { Totally protected species }\end{array}$ & Not more than MYR 100,000 \\
$\begin{array}{l}\text { Specific species: } \\
\text { Crested Argus (Rheinardia ocellata) }\end{array}$ \\
$\begin{array}{l}\text { Mountain Peacock Pheasant (Polyplectron inopinatum) } \\
\text { Great Argus (Argusianus argus) }\end{array}$ & $\begin{array}{l}\text { MYR 30,000 - MYR 100,000 (Shall on } \\
\text { than thirty thousand ringgit and not more than } \\
\text { Green Peafowl (Pavo muticus) } \\
\text { one hundred thousand ringgit) }\end{array}$ \\
$\begin{array}{l}\text { Rhinoceros Hornbill (Buceros rhinoceros) } \\
\text { Plain-pouched Hornbill (Aceros subruficollis) }\end{array}$ & \\
\hline
\end{tabular}


The information on fine and penalty rates provided in Part VII Offences and Penalties in Act 716 is then linked to First Schedule and Second Schedule of Part IX General in Act 716. The first schedule and second schedule provide list of species of birds that are categorised as protected wildlife and totally protected wildlife, respectively. Hence, the bird species listed under first schedule are worth as much as value of fine and penalty rate of Chapter 1 and bird species listed under second schedule have as much value in monetary terms as the value of fine and penalty rate of Chapter 2 .

\section{Calculation Formula on Monetary Valuation}

Calculation on total monetary value of birds could be done by multiplying each individual number of birds with the penalty rate stipulated under Wildlife Conservation Act 2010 (Act 716) as formulated below;

$\mathrm{C}=\sum\left(a_{1} \mathrm{X} b_{1}\right)+\left(a_{2} \mathrm{X} b_{2}\right)$

Where:

$a_{1}=$ number of individual (protected species)

$a_{2}=$ number of individual (totally protected species)

$a=$ rate for protected species (minimum is RM 20,000 and maximum is RM 50,000)

$a_{4}=$ rate for totally protected species (minimum is RM 30,000 and maximum is $\mathrm{RM}$ 100,000)

$\mathrm{C}=$ monetary value of birds

\section{Results and Discussion}

\section{Data on bird population according to their protection status by Act 716}

Extracted data on the bird population at Kenyir rainforest shows 94 individual birds belonging to 25 different species were categorised as either a protected species or totally protected species according to First and Second Schedule of the Wildlife Conservation Act 2010 (Act 716). The results of the data are shown in Table 3.

\section{Calculation on Monetary Value of Birds}

By using the formula $\mathrm{C}=\sum\left(a_{1} \mathrm{X} b_{1}\right)+\left(a_{2} \mathrm{X} b_{2}\right)$, the calculation of the monetary value on birds population is shown in Table 4 below:

According to information in Table 3, based on protection status by Act 716, 69 out of 98 total individuals captured were categorised as totally protected species and none of them were protected species. Protected species means any birds specified in the First Schedule and totally protected species means any birds specified in the Second Schedule of Act 716. 25 birds from these 2 species Pycnonotus goiavier (Yellow-vented Bulbul) and Acridotheres javanicus (Javan Myna) were highlighted as their protection status was "unidentified" as the species was not listed under Act 716.

There is a likelihood that the bird population at the Kenyir rainforest might be worth more with a more surveys done since the broad area of the Kenyir rainforest was not fully researched. The results of the calculations of the monetary value of the individual birds according to their protection status by Act 716 in the study area was estimated to be between a minimum of RM 2.07 million and a maximum of RM 6.9 million. This valuation method also should be highlight as a direct conversion and only reflect part of bird biodiversity value. Their total value to the ecosystem of course much more and complex. The total biodiversity value of birds to ecosystem should be expanded to include other component of ecosystem services, for example, as seed dispersers or pollinators.

The main principle of this valuation method is the value estimated totally depending on the number of individuals of birds captured at study area and their protection status by Act 716. Therefore, this method could be applied to estimate the monetary value of bird population at any ecosystem where research on the bird population, species, type, and number has been carried out before.

This valuation method is alternative to most applied method, Contingent Valuation Method (CVM). CVM involves ascertaining how much 
Table 3: Data on bird population and their protection status by Act 716

\begin{tabular}{|c|c|c|c|}
\hline Species & Local name & $\begin{array}{c}\text { No of } \\
\text { individuals }\end{array}$ & $\begin{array}{c}\text { Protection status } \\
\text { under Act } 716\end{array}$ \\
\hline \multicolumn{4}{|l|}{ Near Threatened } \\
\hline Aegithina viridissima & Green Iora & 6 & FP \\
\hline Alcippe brunneicauda & Brown Fulvetta & 2 & FP \\
\hline Anthracoceros malayanus & Black Hornbill & 2 & FP \\
\hline Buceros rhinosceros & Rhinoceros Hornbill & 4 & FP \\
\hline Calyptomena viridis & Green Broadbill & 3 & FP \\
\hline Chloropsis cyanopogon & Lesser Green Leafbirds & 12 & FP \\
\hline Enicurus ruficapillus & Chestnut-naped Forktail & 1 & FP \\
\hline Eurylaimus ochromalus & Black-and-yellow Broadbill & 3 & FP \\
\hline Hydrochous gigas & Waterfall Swift & 7 & FP \\
\hline Iole olivacea & Buff-vented Bulbul & 6 & FP \\
\hline Megalaima mystacophanos & Red-throated Barbet & 4 & FP \\
\hline Megalaima rafflesii & Red-crowned Barbet & 2 & FP \\
\hline Meiglyptes tukki & Buff-necked woodpecker & 1 & FP \\
\hline Oriolus xanthonotus & Dark-throated Oriole & 2 & FP \\
\hline Pericrocotus igneus & Fiery Minivet & 3 & FP \\
\hline Platylophus galericulatus & Crested Jay & 1 & FP \\
\hline Pycnonotus cyaniventris & Grey-bellied Bulbul & 2 & FP \\
\hline Pycnonotus eutilotus & Puff-backed Bulbul & 1 & FP \\
\hline Pycnonotus goiavier & Yellow-vented Bulbul & 19 & unidentified \\
\hline Pycnonotus squamatus & Scaly-breasted Bulbul & 1 & FP \\
\hline Rhizothera longirostris & Long-billed Partridge & 1 & FP \\
\hline \multicolumn{4}{|l|}{ Vulnerable } \\
\hline Acridotheres javanicus & Javan Myna & 6 & unidentified \\
\hline Chloropsis sonnerati & Greater Green Leafbirds & 1 & FP \\
\hline \multicolumn{4}{|l|}{ Endangered } \\
\hline Meiglyptes tristis & Buff-rumped Woodpecker & 3 & FP \\
\hline \multicolumn{4}{|l|}{ Critically Endangered } \\
\hline Rhinoplax vigil & Helmeted Hornbill & 1 & FP \\
\hline \multicolumn{2}{|c|}{ Total number of individual } & 94 & \\
\hline \multicolumn{2}{|c|}{ Unidentified status under Act 716} & 25 & \\
\hline
\end{tabular}

Table 4: Calculation on monetary valuation on bird value

\begin{tabular}{lcc}
\hline & Protected species & Totally Protected species \\
\hline Total number of individuals & 0 & 69 \\
\hline Minimum value (MYR) & 20,000 & 30,000 \\
Maximum value (MYR) & 50,000 & 100,000 \\
\hline $\begin{array}{l}\text { Monetary value calculated } \\
\text { (MYR) }\end{array}$ & 0 & $2,070,000-6,900,000$ \\
\hline Total monetary value (MYR) & Min value is $\mathbf{2 , 0 7 0 , 0 0 0}$ and Max value is $\mathbf{6 , 9 0 0 , 0 0 0}$ \\
\hline
\end{tabular}


an individual is willing to pay (WTP) to ensure that the existence and heritage attributes of the bird species are preserved. However, the weakness of CVM is the value are estimated based on the value of Willingness to Pay (WTP) which is sometimes does not reflect the actual value of birds in ecosystem.

\section{Conclusion}

This study is helpful in enhancing the exploration of methodology to valuate the monetary value of biodiversity product or service provided by ecosystem especially birds population. Expressing the value of birds in monetary unit is an important fundamental step to raise awareness and perception of the public on the value of wildlife from the perspective of Malaysia law. The monetary valuation can provide a powerful and much needed tool to influence decisionmaking in forest development and conservation. Furthermore, the measurement of their value in monetary units is a fundamental step towards generating expenditure values needed as a tool to measure the effectiveness of conservation and sustainable management initiatives of biodiversity resources, for example in preparation for the implementation of payment for ecosystem services (PES).

\section{Acknowledgements}

The authors would like to acknowledge TNB Seeding Fund through grant number U-TGRD-19-06, Universiti Tenaga Nasional Malaysia for technical and financial support.

\section{References}

Amiry, S. A., Yacob, M. R., Radam, A., Samdin, Z., \& Shuib, A. (2009). Recreational demand in bird sanctuary: The case of Kapar Bird Sanctuary, Kelang, Malaysia. International Journal of Business and Management, 4(12), 99-111.

BirdLife International. (2019). Country Profile: Malaysia. Accessed 15 January 2019, from http://www.birdslife.org/datazone/country/ malaysia.

Costanza, R., de Groot, R., Sutton, P. C., van der Ploeg, S., Anderson, S., Kubiszewski, I., Farber, S., \& Turner, R. K. (2014). Changes in the global value of ecosystem services. Global Environmental Change, 26, 152158.

David, G., Roslan, A., Azhar, I., \& Abdullah, M. T. (2017). Checklist of birds in Tanjung Mentong, Terengganu, Peninsular Malaysia. Journal of Wildlife and Parks, 32, 85-92.

David, G., Roslan, A., Mamat, M. A., Hamza, A. A., \& Abdullah, M. T. (2017). An annotated checklist of migratory birds in Kenyir, Setiu and Pulau Perhentian Besar, Terengganu, Malaysia. Journal of Sustainability Science and Management, 12(2), 135-160.

De Groot, R., Brander, L., Costanza, R., Bernand, F., Braat, L., Christie, M., \& Van Beukering, P. (2012). Global estimates of the value of ecosystems and their services in Monetary Units. Ecosytem Services, 1, 50-61.

Duncan, A. L., David, B., \& Maketab, M. (2014). A National Red List for the birds of Malaysia. Journal of Wildlife and Parks, 28, 41-49.

Foong, S. Y., Yeap, C. A., \& Butt, C. (2016). A pilot rapid assessment of selected ecosystem services provided by the Teluk Air TawarKuala Muda Coast IBA in Pulau Pinang. Kuala Lumpur: Malaysian Nature Society. (MNS Conservation Publication No. 16).

Government of Malaysia. (2010). Laws of Malaysia, Act 716, Wildlife Conservation Act 2010. Kuala Lumpur: Percetakan Nasional Malaysia Berhad. 137 pp.

IUCN. (2016) The IUCN Red List of Threatened Species. Version 2016-3. http://www. iucnredlist.org. [accessed 16 March 2019].

Jabatan Perhutanan Semenanjung Malaysia. (2017). Economic valuation on forest biodiversity at Perak Permanent Reserve Forest. Kuala Lumpur: JPSM. 
Kellermann, J. L., Johnson, M. D., Stercho, A. M., \& Hackett, S. (2008). Ecological and economic services provided by birds on Jamaican Blue Mountain Coffee Farms. Conservation Biology, 22, 1177-85.

Kenyirlake.com (2020). Flora and Fauna. Accessed 20 February 2019, from https:// kenyirlake.com/flora_fauna.

Kolstoe, S., \& Cameron, T. A. (2017). The non-market value of birding sites and the marginal value of additional species: Biodiversity in a random utility model of site choice by eBird Members. Ecological Economics, 137, 1-12.

Mansor, M. S., \& Sah, S. A. M. (2012). The influence of habitat structure on bird species composition in Lowland Malaysian Rain Forests. Tropical Life Sciences Research, 23(1), 1-14.

Millenium Ecosystem Assessment. (2005). Ecosystems and human well-being synthesis. Washington, DC: Island Press.

MNS-Bird Conservation Council. (2010). A checklist of the birds of Peninsular Malaysia. Kuala Lumpur: Malaysian Nature Society. (MNS Conservation Publication No. 10).

Nelson, B. R., David, G., Mokhtar, A. F., Mamat, M. A., \& Rahman, A. (2018). Avian data from Kenyir Rainforest Trail. Data in brief, 21, 2633-2637.

Norfaizal, G., Mohd., Masrom, H., \& Muhammad Radzali, M. (2015). Flora diversity of Pulau Tekak Besar, Tasik Kenyir, Hulu Terengganu, Malaysia.
International Journal of Current Research in Biosciences and Plant Biology, 2(5), 179-183.

O'connell, T. J., Laura E. Jackson, L. E., \& Brooks, R. P. (2001). Bird guilds as indicators of ecological condition in the Central Appalachians. Ecological Applications, 10(6), 1706-1721.

Sulaiman, M. H., Embong, M., Mamat, M. A., Tahir, N. F. D. A., Latip, N. A., Murni, R., \& Azhar, M. (2015). Preliminary survey of the bird assemblage at Tanjong Mentong, Lake Kenyir, Hulu Terengganu Malaysia. Tropical Natural History, 15(1), 87-90.

Wenny, D. G., Devault, T. L., Johnson, M. D., Kelly, D., Sekercioglu, C. H., Tomback, D. F., \& Whelan, C. J. (2011). Perspectives in ornithology: The need to quantify ecosystem services provided by birds. The Auk, 128(1), 1-14.

Whelan, C. J., Sekercioglu, C. H., \& Wenny, D. G. (2015). Why birds matter: From economic ornithology to ecosystem services. Journal of Ornithology, 156, 227-238.

Whelan, C. J., Wenny, D. G., \& Marquis, R. J. (2008). Ecosystem services provided by birds. Annals of the New York Academy of Sciences, 1134, 25-60.

Yeap, C. A., Sebastian, A. C., \& Davison, G. W. H. (2007). Directory of important bird areas in Malaysia: Key sites for conservation. Kuala Lumpur: Malaysian Nature Society. (MNS Conservation Publication No.8). 


\section{Appendix}

\section{Appendix I}

First Schedule on Protected Wildlife of Bird Species as described in Part IX, Malaysia Wildlife Conservation Act 2010.

WILDLIFE CONSERVATION ACT 2010

PART IX

First Schedule

Protected Wildlife (Birds)

\begin{tabular}{lll}
\multicolumn{1}{c}{ Family } & Scientific Name & Common Name \\
\hline $\begin{array}{l}\text { Charadriidae } \\
\text { (Plovers) }\end{array}$ & \multicolumn{1}{c}{ CLASS AVES (BIRDS) } \\
\hline $\begin{array}{l}\text { Columbidae } \\
\text { (Doves, pigeons) }\end{array}$ & Chalcophaps indica & Eastern Dotteral \\
\cline { 2 - 3 } & Treron olax & Emerald Dove \\
\cline { 2 - 3 } & Treron vernans & Little Green Pigeon \\
\cline { 2 - 3 } & Treron seimundi & Pink-necked Green Pigeon \\
\hline $\begin{array}{l}\text { Dromadidae } \\
\text { (Crab plover) }\end{array}$ & Dromas ardeola & Seimunds's Pintail Pigeon \\
\hline $\begin{array}{l}\text { Phasianidae } \\
\text { (Jungle, Fowl, Quail) }\end{array}$ & Coturnix chinensis & Crab Plover \\
\hline $\begin{array}{ll}\text { Rallidae } \\
\text { (Rail) }\end{array}$ & Gallus gallus & Painted Quail \\
\hline $\begin{array}{l}\text { Scolopacidae } \\
\text { (Snipe, stint) }\end{array}$ & Amaurornis phoenicurus & Red Jungle Fowl \\
\cline { 2 - 3 } & Poliolimnas cinereus & White-breasted Waterhen \\
\hline & Calidris subminuta & White-browed Rail \\
\cline { 2 - 3 } & Gallinago gallinago & Long-toed Stint \\
\cline { 2 - 3 } & Gallinago nemoricola & Common Snipe \\
\cline { 2 - 3 } & Gallinago pratincola & Wood Snipe \\
\hline
\end{tabular}

* For full list, please refers to Laws of Malaysia, Act 716, Wildlife Conservation Act 2010 (2010). Part IX General, First Schedule 


\section{Appendix II}

Second Schedule on Totally Protected Bird Wildlife Species as described in Part IX, Malaysia Wildlife Conservation Act 2010.

WILDLIFE CONSERVATION ACT 2010

PART IX

Second Schedule

Totally Protected Wildlife (Birds)

Family

Scientific Name Common Name

\begin{tabular}{lll}
\hline \multirow{2}{*}{$\begin{array}{l}\text { Accipitridae } \\
\text { (Hawks, Eagles) }\end{array}$} & Accipiter badius & Shikra Goshawk \\
\cline { 2 - 3 } & Accipiter gularis & Japanese Sparrowhawk \\
\cline { 2 - 3 } & Accipiter soloensis & Chinese Goshawk \\
\cline { 2 - 3 } & Accipiter trivirgatus & Created Goshawk \\
\cline { 2 - 3 } & Accipiter virgatus & Besra \\
\hline Aegypius monachus & Cinereous Vulture \\
\hline Aquila clanga & Greater Spotted Eagle \\
\hline Aquila heliaca & Imperial Eagle \\
\hline Aquila nipalensis & Steppe Eagle \\
\hline Aviceda jerdoni & Jerdon's Baza \\
\hline Aviceda leuphotes & Black Baza \\
\hline Butastur indicus & Grey-faced Buzzard Eagle \\
\hline Buteo buteo & Common Buzzard \\
\hline Circaetus gallicus & Short-toed Eagle \\
\hline Circus aeruginosus & Western Marsh Harrier \\
\hline Circus cyaneus & Northern harrier \\
\hline
\end{tabular}

* For full list, please refers to Laws of Malaysia, Act 716, Wildlife Conservation Act 2010 (2010). Part IX General, Second Schedule. 